\title{
Which Pension?: Women, Risk and Pension Choice1.
} Kay Peggs

This is an accepted, postprint version of the published manuscript - Peggs, $\mathrm{K}$ (2000) Which Pension?: Women, Risk and Pension Choice'. The Sociological Review, 48 (3): 349-364.

\begin{abstract}
This paper investigates women's perceptions of choice and risk in the field of pensions. It extends on a paper published in a recent edition of this journal in which Alan Aldridge applied Pierre Bourdieu's notions of cultural capital and habitus to the field of personal finance. Since the late 1980s the marketisation of pensions has resulted in an expansion of pension options. According to Anthony Giddens the expansion of choice is one of the positive aspects of living in a 'risk society'. However, the expansion of pension choice has passed pension risks onto consumers. Using qualitative interviews this paper investigates the perceptions of 45 employed women aged 40-59 of the risks associated with choosing a pension. At the theoretical level the paper seeks to demonstrate the need to qualify notions of reflexive decision-making put forward by Giddens by emphasising the role of habitual action in decision-making, as put forward by Bourdieu. The paper shows that material circumstances, cultural capital, extent and quality of pension information and habitus affect perceptions of pension choice and pension risks. The paper concludes that the expansion of pension choice has been negative rather than positive and thus is likely to lead to increasing poverty among women in later life.
\end{abstract}

\section{Which Pension?: Women, Risk and Pension Choice.}

One of the positive aspects of living in the 'risk society' (Beck 1992) we are said to live in is the expansion of choice (Giddens 1998). However, 'choice is differentially distributed according to class and income' (Giddens 1998: 30) and we can add life course position, gender and ethnic origin. In this paper I use empirical data to examine perceptions of choice and risk in decision-making in the field of pensions. My focus is on the perceptions of women in mid-life of the pension options available to them, because research shows that women are less likely than men to have access to all pension options (Ginn and Arber 1993, Groves 1991, Walker 1992). Since we live in a moral climate where we are expected to make choices and assume responsibility for our fate (Smart 1999), and where we take increasing responsibility for our own welfare (Aldridge 1998), an analysis of perceptions of pension risks and the management of those risks is worthy of attention.

The idea of risk is linked with thoughts of controlling the future and making it safe (Giddens 1998). The majority of women and men in the UK expect to retire, but how they save for retirement is, by all accounts, a risky and unsafe business.

1 This is a revised version of the paper 'Which Pension?: mid-life women and pension choice in the UK' presented to the IVth European Congress of Gerontology, Berlin, 7-11 July 1999. 
Government changes to state pensions, the mis-selling of private pensions and the stealing of assets of occupational pensions have highlighted the risks we take as consumers of pensions. The marketisation of pensions in the UK, with its emphasis on private schemes, is part of the rolling back of the welfare state with risks and costs being passed on to consumers (Aldridge 1998). Thus UK governments in the 1980s and 1990 s are less willing to guarantee financial security during pension years (Falkingham 1998). The effect of such policies on the pension provision and retirement income of women has been examined in an increasing amount of research (Davies and Ward 1992, Ginn and Arber 1993, 1998, Groves 1991, Walker 1992). Since women make up the majority of people of pension age, any negative outcomes of pension choices made at earlier stages of the life course disadvantage women disproportionately. This paper focuses on the ways in which women make decisions when confronted with pension options. It investigates theoretical ideas about the decision-making process by examining the empirical data in the light of theories of choice, which emphasise a calculative, rational perspective and those which emphasise the place of 'irrational' behaviour.

The paper begins with an outline of theoretical perspectives on how individuals make choices in the face of risk. This is followed by a brief discussion of how discourses associated with consumer choice have been incorporated into UK pension policy in the 1980s and 1990s. I then turn my attention to my empirical study. After a brief outline of the methods and data used I present and analyse the interview data. My conclusions return me to more theoretical issues and provide a context for reflection on how mid-life women negotiate risk and choice in planning their future pension incomes. This leads me to qualify the notion of reflexive decision-making put forward by Giddens by emphasising the role of habitual action in decision-making. The paper concludes that the expansion of pension choice has been negative rather than positive, and thus is likely to lead to increasing poverty among women in later life.

\section{making choices in the face of risk}

If indeed we do live in a risk society, how do we make decisions when confronted with what Giddens calls 'panoramas of choice' (1991: 139)? For Giddens the key is 'reflexivity', which involves the continual weighing up of different positions in the light of new information; reflexivity thus undermines the certainty of knowledge (1991:20). Consequently, individuals employ a 'calculative attitude to the open possibilities of action' (1991: 28). To make choices often we need access to complex systems of information, thus reflexivity increasingly takes place through expert systems. Since experts often disagree such systems are reliant on the trust of lay people. For Giddens, reflexivity can lead to the empowerment of individuals since they can 'reskill' while in the process of weighing up positions (1991: 138-9). So, thinking about pension choice, marketisation is predicated on consumers who are active and informed and who do not just defer to experts (Aldridge 1998). Thus individuals appropriate knowledge about pensions in order to make a decision. This notion of reflexivity is not without its critics.

Pierre Bourdieu (1984) does not see the conscious and deliberate intentions of calculating (reflexive) individuals as an adequate explanation of how we make choices 
(Aldridge 1998). His notion of the habitus, for example, points us to the pre-conscious non-reflexive ways in which people act. Chris Shilling (1993) describes the habitus as an internalised set of predispositions to act in certain ways, determined by the various factors consisting an individual's social location. For Bourdieu, individuals acquire their habitus as part of their personal development within a social field, that is within a 'structured system of social positions [that] includes lifestyle, education and politics' (Jenkins 1992: 84-85). So, ultimately, for Bourdieu, it is the less than conscious dispositions of the habitus that produce actions (Jenkins 1992: 77), and not the calculations of the rational actor put forward by Giddens. In a recent edition of th is journal Alan Aldridge (1998) has shown that the concept of the habitus can be applied successfully to consumer behaviour in the area of personal finance. I intend to show how the notion of reflexivity can be qualified with the concept of habitus to provide a useful model of decision-making in the field of pensions.

risk and choice: pensions since 1988

Changes to UK pension policy since 1988 have been defended by a rhetoric of choice. In the field of pensions the state has been declared a barrier to choice and freedom, and thus 'the burden of the state' was removed in order to maximise consumer power (Gabriel and Lang 1995). Thatcherite discourse relied on keywords like 'choice' and phrases like 'power to choose' (Phillips 1998: 854), and individual responsibility has become a prominent feature of social and political discourses (Smart 1999). The emphasis is on the need to be self-sufficient and owe as little as possible to others (Leadbetter 1989). This rolling back of the state has meant that financial risks have been passed on to consumers (Aldridge 1998), and choice has been linked to notions of good and evil and right and wrong (Gabriel and Lang 1995).

Employees paying National Insurance Contributions (NICS) have no choice but to make pension contributions. However, within this constraint, since 1988 those with access to all second-tier pension options can choose between an occupational scheme, an Appropriate Personal Pension (APP) or to remain in the State Earnings Related Pension Scheme (SERPS). To facilitate choice the 1988 legislation allowed employees to opt out of occupational pensions that had previously been compulsory and occupational pension scheme membership can no longer be a condition of employment (Reardon 1994) ${ }^{1}$. Changes proposed by the present Labour Government will modify the available pension options to include the Second State Pension (SSP) and new stakeholder pensions (Secretary of State for Social Security 1998). The new SSP will replace SERPS and will provide benefits superior to those of SERPS for those earning up to $f 9,000$ a year (Agulnik 1999). In the absence of an occupational scheme employers will have to offer new stakeholder schemes to their employees, who will be encouraged to opt into them if they earn $£ 9,000$ or more a year (Secretary of State for Social Security 1998). Thus it seems that the number of second-tier options will increase, covering the SSP, stakeholder pensions, occupational pensions and APPs.

Choosing a pension is complicated and risky. APPs are money purchase schemes with no set relationship between earnings and pension since returns are based on contributions and investment performance (Waine 1995). So, APPs are often inferior to salary-related schemes such as SERPS and many occupational 
schemes that provide a guaranteed link between pension and earnings. However, since APPs are not tied to an employer they have been marketed as more 'flexible' and a better option for women, often against their best interests (Davies and Ward 1992). Between 1988 and 1993 incentives, such as tax relief (Waine 1995), along with the emphasis on choice meant that millions of consumers were encouraged to opt out of established state pensions and take out these new private schemes (Gabriel and Lang 1995). However, by 1994, when regulations were tightened, there was a scandalous number of cases of mis-sold APPs where individuals were advised to take out, or transfer to, APPs that were wholly against their best interests (Your Pension 1998).

Pension choice has often been based on limited information, lack of knowledge and fear. Fears about the future of state pensions has meant that many have switched from SERPS to non-state schemes (Vincent 1995). Occupational pensions are often taken up with very little thought, and scheme members have very little knowledge about them (Field and Farrant 1993, Williams and Field 1993). So, the complex literature associated with occupational schemes does little to aid understanding (Field and Farrant 1993). Only a minority of those with an APP feel they have a very good understanding of them (Williams and Field 1993) and the advice that women receive takes little or no account of their disrupted employment lives (Davies and Ward 1992).

Pension choice is not available in the same proportions to all and the notion of choice is often meaningless to those with limited financial resources (Nettleton and Burrows 1998). Occupational pensions are usually the financially better option but women are less likely than men to work for an employer who runs a scheme (Ginn and Arber 1993, Peggs 1995). Moreover, low earners are likely to be better off if they choose to stay in SERPS than if they opt for an APP (Davies and Ward 1992) or more recently available money purchase occupational pensions (Hutton et al. 1995). The present Labour Government states that 'the pension system we inherited...risks leaving up to a third of future pensioners facing poverty' (Secretary of State for Social Security 1998: 1, para 5). Since the majority of pensioners are women these negative effects are gendered.

In summary, successive UK governments have emphasised the notion of choice in the area of retirement pensions. The expansion of choice, information and regulation means that individuals are likely to be held increasingly responsible for the pension choices they make. Since women, on average, have fewer pension options than men, it is likely that they will be the victims of this 'rhetoric of responsibility' (Smart 1999: 89). The study that follows explores how a sample of mid-life women perceives the risks and choices associated with pensions.

\section{data and method}

The interviews presented below are part of a multi-method study carried out between 1991 and 1995 into women and pensions. The research examines structural features of women's pension membership (in particular non-state pensions) in Britain using General Household Survey data, and provides insights into women's perspectives on pensions using qualitative interviews. This paper is based on the qualitative part of the 
study, which aimed to identify perspectives on state and non-state pension membership and attitudes to future financial independence. Although the sample is not intended to be representative it provides valuable insights into the subjective understandings of a diverse range of interviewees.

For this part of the study I interviewed 45 employed women aged $40-59$. This focus on employed women was necessary since contributions to second-tier pensions are confined to employees. The age range of 40 - 59 was chosen because many women of this age who have had children have a high level of labour market participation because their children have left the parental home (Arber and Gilbert 1992).

The sample was gained using a snowball technique of gathering contacts from each interviewee. I stratified the sample according to part-time and full-time employment since hours in employment impacts significantly on non-state pension membership (Ginn and Arber 1993, Peggs 1995). The sample consists of 30 full-timers (doing 31 or more hours a week) who were offered an occupational pension (15 had taken up the scheme and 15 had not). An additional 15 were part-timers (doing up to 30 hours a week) who were not offered occupational scheme membership. The labour market characteristics of the sample are presented in table 1. Twenty six of the interviewees were married. The majority (43) of the women interviewed identified their ethic origin as white, one as black as one as Asian. Consequently issues around ethnicity are not explored here.

Table 1: Labour Market Characteristics of the sample by second-tier pension membership

\begin{tabular}{|l|c|c|c|c|}
\hline & \multicolumn{4}{|c|}{ Second-Tier Pension (n) } \\
\hline & Occupational & APP & SERPS & None \\
\hline Part Time Employed & 0 & 6 & 4 & 5 \\
Full Time Employed & 15 & 4 & 11 & 0 \\
\hline Occupational Class* & & & & \\
1. Managerial/Professional & 4 & 4 & 4 & 2 \\
2. Routine Non-Manual & 9 & 3 & 3 & 1 \\
3. Skilled Manual & 0 & 0 & 0 & 0 \\
4. Semi Skilled Man/Service Occs & 2 & 2 & 7 & 0 \\
5. Unskilled Manual & 0 & 1 & 1 & 2 \\
\hline Annual Earnings & & & & \\
Up to $£ 5,000$ & 0 & 4 & 3 & 5 \\
£5001 - f10,000 & 8 & 2 & 7 & 0 \\
£10,001- $£ 15,000$ & 6 & 3 & 5 & 0 \\
$£ 15,001+$ & 1 & 1 & 0 & 0 \\
\hline Total N & 15 & 10 & 15 & 5 \\
\hline
\end{tabular}

* Using the Registrar General's Occupational Classification (OPCS 1990) collapsed into five categories.

I used open-ended, but focused qualitative interviews, since this allowed the women to expand more fully on their attitudes. I identified general topic areas ${ }^{2}$ which 
enabled the interviewee's responses to determine topic order, the time spent on each topic and the introduction of additional issues. A grounded theory approach (Glaser and Strauss 1967) was used so that, as new themes emerged, they were followed up in subsequent interviews. The taped interviews were between 30 minutes and two hours in length and were conducted between May and November 1992.

For all data analysis the researcher brings her or his own basic assumptions, patterns of thinking and knowledge gained from experience and reading (Strauss and Corbin 1990: 95). In interview data concerned with attitudes this is particularly problematic since issues of establishing equivalence of meaning between interviewer and interviewee must be addressed (Fielding 1993). The grounded theory approach to data analysis (Strauss and Corbin 1990) and Agar's (1986) analytical approach were particularly useful in this respect. The interviews provided a wealth of information leading to the emergence of major themes. The themes drawn on here relate to the issues that affected women's pension membership decisions, and the role that information and experts played in these decisions.

\section{women's perspectives on pension choice}

Each interview began with a discussion about the interviewee's pension membership. Thirty of the women were interviewed because they had all three second-tier options. Four of the 15 who had taken up an occupational scheme said that membership had been a condition of employment, before legislative changes in April 1988 prohibiting this practice.

Jill 'The actual job has always had a pension attached to it and it was compulsory at one stage, so I've always had it, so it was just part of the outgoings of your salary, so we didn't really need to give it much thought' (Occupational scheme member for 11 years ${ }^{4}$ ).

Sally 'When I started I was forced to join and I've never stopped since' (Occupational scheme member for 15 years).

Sheena 'I didn't choose to pay superannuation, it is compulsory. I'm sure it just appeared on my wage slip, that they'd docked me so many pounds for the month' (Occupational scheme member for 5 years).

Since membership had not been a choice any risks associated with occupational schemes were not voluntarily taken. However, although those who were compelled to join complained that they had received little information about the benefits of joining (discussed below) all felt grateful that they were now members.

In assessing the risks associated with present employment a minority of the women saw taking a job with an occupational scheme, compulsorily or voluntarily attached, as less risky than taking a job that did not offer such fringe benefits. 
Ava 'I wouldn't ever go into jobs that didn't have unions, didn't have pension schemes and didn't have health and safety.' (Occupational scheme member for 19 years).

Sally 'I wouldn't get a job without a pension attached to it - but in my type of work a pension is always attached' (Occupational scheme member for 15 years).

These women had all three pension options and the 'calculative attitude' posited by Giddens (1991: 28) is evidenced in these extracts. For these women, present and future risks were part of the same choice; employers who did not offer a range of fringe benefits were seen as risky employers, affecting present employment conditions and putting future retirement income at risk. The employment and pension options open to them and their perceptions of, and management of, the risks they associated with these options are established over the life course. Their career patterns, their location within social milieu and within networks of communication (Macgill 1989) has led them to expect, and strive for, a range of current and future benefits from their jobs. However, not all the women interviewed had similar access to a range of options. Most of the part-timers said that responsibilities for child care prevented them from considering full-time employment. None of them were offered an occupational scheme and therefore had, at most, two pension options. Those on earnings below the NIC level were not paying into SERPS and therefore could only opt for expensive personal pensions, contributions to which were frequently prohibitive.

Liz 'I would [join] now. I mean the occupational pension contribution area is always assessed according to earnings anyway and then it's backed up by a contribution by an employer, and if I had a full-time job now, I would be somewhat better off. But I think I regard this job as temporary...If women saw themselves in that bread-winning role they would be planning ahead but all the time its second to caring we'll never plan ahead'. (No second-tier pension, earnings too low for SERPS).

Women with limited resources have limited choices. Women's social location, which is determined by, for example, familial and financial constraints, the expectation that women's primary role is located in the home, and changes in the labour market, often prevents those who are poorer from having access to a range of job options.

Moreover, women's notions of their roles operate at the pre-conscious level of the habitus, pointing to non-reflexive choices. Liz directs us to the problems associated with pension choice for women in a social system where women's primary role is socially constructed as carer, where women see their primary role as mothers, but where the pension system is based on attitudes associated with traditional male patterns of employment.

In 1988 occupational pension membership became voluntary and those who had been compelled into membership spoke about the choices they had made regarding this change. 
Dora 'They had this big thing, didn't they, about opting out. To be honest with you I can't remember why it wasn't worth it for me' (Occupational scheme member for 16 years).

Myra '...l'd been in this scheme too long to get out of it, it wasn't worth it for me' (Occupational scheme member for 2 years).

This decision to remain with the current pension rather than transfer to a newly available option was reflected by APP members.

Dawn 'When they started it [the occupational scheme], I'd already got a private scheme, so I just kept going, and I thought it was stupid to transfer it'. (Offered an occupational scheme but already in APP. APP member for 2 years).

Making a choice can be very difficult and littered with uncertainty (Melucci 1996). This difficulty is compounded where individuals are expected to take personal responsibility for the choices they make. Although some form of calculation might be used, the habitus often guides individuals into strategies of avoidance (Aldridge 1998). Aldridge remarks that in the field of personal finance such strategies include 'avoidance of potentially disconfirming information' (1998: 5). So, individuals are often conservative when making choices. In the complex field of pensions it can be easier to stick with the devil you know rather than the devil you don't.

The management of choice and risk is often based on trust (Giddens 1991). Concerning government policy Anna Coote suggests that 'Trust has broken down because politics is characterised by secrecy, spin-doctoring and special pleading' (1998: 126). In the case of pensions, many people in the UK have chosen a non-state pension over a state pension because of a lack of confidence in government commitment to the state scheme (Vincent 1995). Several of the women in non-state pensions stated that the risk of government changes to state pensions had affected their pension choice.

Ava 'It's [SERPS] a con. They couldn't possibly pay out that over all those years. I knew when I left the civil service that they couldn't possibly pay us, and they must have known it, so it is just another way of getting money into the Tory bloody coffers' (Occupational scheme member for 19 years).

April 'At that time I'd been a member of the Labour Party for years and at the time I was quite het up. It seemed that the contributory pension was not going to be continued, and it was going to waste away, and the Government was actually going to trash it. There was a lot of talk of how useless it was, and it was a waste of money for the country, and everybody should be on their private pensions. I felt it was literally giving your money to strangers, and you didn't know what those strangers were going to do with it, and they could be investing in something I am not happy with, but I wouldn't know.... I would want to know where the money went and this Maxwell thing is disgraceful'. (Offered occupational scheme but chose SERPS) 
Lack of trust in the commitment of governments to state pensions has assisted the drive to encourage people to transfer to non-state schemes. Nevertheless, problems with occupational pensions and APPs meant that most of the interviewees had misgivings about choosing a non-state scheme as well. The Maxwell scandal has generated grave doubts about the safety of money invested in occupational pensions. The scandal of mis-sold APPs has further eroded public confidence in non-state schemes.

Although trust had been knocked the notion of the moral imperative to take out a non-state scheme was remarked upon by a few of the interviewees.

Wanda 'People of my generation were the people who started to stand on their own two feet but we're not like them young girls today who are brought up to think along those lines, not to rely on the state, to donate to a private pension. They ought to be obliged to pay so much to a private pension - they shouldn't expect the government to fork out...I used to think I'd have the state pension...Until a few years back, women were going to get a state pension, but gradually the state is getting less. But you can understand it because there are loads of people of our age who will be retiring, and there won't be enough money in the kitty. If you haven't got a private pension you've had it' (Offered an occupational scheme but chose an APP. APP member for 1 year).

The idea of individual responsibility has emphasised the need to be self-sufficient. Contrary to Bourdieu's notion of the habitus as being formed during early socialisation, we come across some social fields only as adults (Jenkins 1992: 90). The idea of individual responsibility became prominent in the 1980s and, as a result, some of the women had changed their minds about which pension option they should choose, the moral imperative being to choose a non-state scheme.

\section{choosing a pension: the role of experts and information}

For Anthony Giddens the 'reflexive monitoring of risk' (1991: 119) entails increasing contact with expert systems. Since knowledge in late modernity is constantly revised, individuals often take expert advice to help them make decisions. However, decisions rarely become 'clear-cut' as a result of such consultations since experts often disagree amongst themselves. Giddens sees this as a site of potential empowerment for lay people since they can appropriate knowledge while trying to make a decision. He states that 'if a person takes the trouble to reskill appropriately, a reasonably informed choice can in fact be made' (1991: 141). Such a conception overlooks the ways in which individuals deal with information. Aldridge (1998) argues that much of the population does not possess, in Bourdieu's terms, the 'cultural capital' (broadly the knowledge and proficiency needed to make a decision), to resist marketing strategies and to understand the literature put before them. Aldridge concludes that lack of cultural capital 'prepares [individuals] for co-operation in their own exploitation' (1998: 1). This perspective does not attribute blame to individuals for the choices they make but rather asserts that cultural capital enables people who are 'better informed', 
'better advised' and have a more 'sceptical habitus' to make favourable choices about personal finances (Aldridge 1998: 21). In this section I explore these notions in respect of the women's perceptions of the pension advice they had received.

In the field of pensions legislative requirements demand that non-state pension providers issue explanatory material for potential members and members. The present Government argues that information is often of poor quality and thus concludes that 'many people run the risk of making the wrong pension choices...' (Secretary of State for Social Security 1998: 27, para 11). The Government advises that 'It is important that consumers should exercise care in the choices they make' (Secretary of State for Social Security 1998: 73 para 43), thus places emphasis that individuals are to be held responsible for their pension decisions. Thus there is an emphasises on individual duty.

Each interviewee was asked about the information and advice they had sought and received. Along with written official information, the women sought advice from financial advisers, friends, colleagues and relatives, and some scanned newspaper articles for information. Most felt that the information they had received was extremely difficult to understand. For the women who were offered an occupational scheme the decision about adopting membership was occasionally influenced by the information provided by employers. However, only a minority (10) of all the women interviewed felt that they had adequate knowledge of pensions, ranging from knowing how much they could expect in retirement to knowing the details of all the options. In most cases the women considered the information to be very poor indeed, and all felt frustrated about its shortcomings.

Myra 'I think you just got the forms telling you you were in a pension scheme in loads of jargon, that you didn't understand, and you just knew that it was going to come out of your wage, so you just accepted that $x$ amount of money was going to come out every month. I've got no idea how much I'll get.' (Occupational scheme member for 2 years).

Leigh 'They did [send information] but it was very difficult to understand because they don't talk in a language you can understand. They talk about what is going to happen when you're 60, and how much its worth, but it's still very difficult to understand. They don't talk in basic language'. (Occupational scheme member for 3 years).

Information received from employers before, and during, membership was considered by most to be equally difficult to understand. The field of pensions is notoriously complicated and without understandable information it is difficult to comprehend how individuals can, in Giddens terms, 'reskill appropriately' to make 'a reasonably informed choice' (1991: 141). On the basis of problems with the information she received one interviewee transferred from her occupational pension to an APP, which is likely to be against her financial interests.

Judy 'I had the opportunity to join this [occupational] one here and everybody said how good it was, so after my six month trial period I was allowed to join 
the scheme, which I did, and when I tried to find out what it would be worth when I retired, I was having trouble finding out details, and since I knew I wouldn't be here for the rest of my working life, I felt it better to come out while I could still get some of the money back, and I could put it into another scheme [an APP]'. (Offered an occupational scheme, transferred to an APP. APP member for 1 year).

It is unlikely that an APP will provide as good a return as an occupational pension scheme. Information and persuasion are inextricably linked in the world of personal finance (Aldridge 1998) with suppliers competing for willing consumers. Aldridge concludes that it is those who have access to cultural capital and thus are better informed who are able to resist such strategies (1998: 21). In the 'promotional culture' (Wernick 1991) of pensions, experts are often seen as charlatans since trust has been seriously knocked by pensions mis-selling. So how did the women choose among different APP providers? Several had chosen on the basis of trusting the advice given by established insurance companies with whom they had dealt for other types of insurance.

Wanda 'Everything in life is a risk and so I'm really being rather naughty for taking a safer option with the [Insurance Company] but then I don't have to worry. I always like to know I've got my own bit of security and its important'. (Offered an occupational scheme but chose an APP. APP member for 1 year).

Sam 'I did it (took out an APP) because the insurance man suggested it, and I'd been looking at the work's pamphlet'. (Not offered an occupational scheme. APP member for 1 year).

The 'strong branding' (Aldridge 1998: 12) of companies with retailing credibility, coupled with familiarity, induced a feeling of trust in the advice given by their advisers. However, many of these companies were implicated in the mis-selling scandal (Aldridge 1998) and women have been disproportionately disadvantaged by commission receiving pension advisers (Pensions Management 1992: 2). Although it was the companies and advisers that were held to blame (Aldridge 1998) in the future the blame is more likely to be laid in the laps of consumers since safeguards have been tightened. Thus the present Government concludes that individuals should be able to gain 'information and advice from sources they can trust' (Secretary of State for Social Security 1998: 85 , para 2).

Nevertheless it seemed that the upsurge in information resulting from the introduction of APPs had a positive impact on awareness of the need for pension planning, especially for those without an option of occupational pension membership who received no pension information from their employers.

Simone 'Its right to have a pension...All the media coverage of SERPS was raising the question. I actually went to a bank adviser in the end and he set it all quite simply out on a piece of paper and we discovered which one had the 
best pension and we, [husband] and I, both got these pensions'. (Not offered an occupational scheme. APP member for 1 year).

Kit 'When they first came out [private pensions]...I actually did training with one company, and I had to show videos about benefits, and I had to show one on pensions, and that actually made me think, because pensions doesn't mean anything, but the video showed all the benefits to different types of people with pensions...but I couldn't take one up there, because I wasn't working enough hours'. (Not offered an occupational scheme. APP member for 1 year).

Such 'no choice situations' are usually the province of the poor (Bauman 1998). Women are less likely than men to have access to financially superior occupational schemes, and to the information that accompanies them, and women in lower paid jobs are usually the most disadvantaged. 
A minority of the women interviewed were better informed about pensions and thus had gained the cultural capital needed to make a more informed choice about pension options. This had been built up over many years since information had been gained from past employers, early in their careers, and thus could inform future pension decisions.

Shirley 'It's all part of your induction when you join the civil service. I joined in 1969 and I was sent off to do training and part of that was terms of employment and pension provision. Before that, when I was 20 , I joined a factory and I think you had to be 24 to join, and the question never arose because I left before then. When I joined the council they gave us lots of information about pensions'. (Occupational scheme member for 1 year).

Ava 'My first job was nursing and it was a really good training hospital, and they had people in to advise you on bank accounts, because they preferred to pay into a bank. So that's how I found out all about bank accounts and pensions'. (Occupational scheme member for 19 years).

Such information enabled Ava and Shirley to consider, in some detail, the pension options open to them and both were sceptical about the security of all pension options. The inadequate information and advice received by most of the women interviewed meant that they had not gained the cultural capital needed to make an informed choice, and thus the choices they had made could damage their finances in later life.

\section{discussion and conclusions}

In his work Anthony Giddens (1991) has suggested that the expansion of choice is one of the positive aspects of living in the 'risk society' we are said to live in. However findings from this study suggest that the expansion of choice, coupled with the marketisation of pensions, has led to increased confusion about which pension option to take. Thus saving for future retirement has become increasingly risky. The material circumstances which contexualise the lives of the women interviewed affect the pension options open to them and the information they receive about pensions. Since we live in a moral climate where we are expected to take more responsibility for own welfare, but where women are less likely than men to have access to more lucrative occupational schemes (Ginn and Arber 1993), it is likely that women will increasingly bear the brunt of, what are seen as, bad pension choices.

Giddens (1991) has emphasised the role of reflexive calculations in decision-making. Although the women interviewed made calculations about what they felt was the best pension option, this decision was frequently based on lack of adequate and understandable information. If pension choice is being made during mid-life a good choice is crucial since valuable contribution years have already been lost. However, like many of us, most of the women lacked the cultural capital needed to make an informed decision. This is not to apportion blame to them; it seems that written and verbal information about pensions is not designed to be consumed by lay people. Thus, without understandable information, it seems unlikely that they will be able to 'reskill appropriately' to make 'a reasonably informed choice' (Giddens 1991: 141). In addition, information is often received as marketing strategies of pension sellers. I agree with Aldridge (1998), those who are better informed and who have a more 'sceptical habitus' are more likely to be able to resist such 
marketing strategies. However, even if all the women in this study were better informed and all did posses a more 'sceptical habitus', the moral imperative to choose a non-state rather than a state pension would drive some with few options into 'choosing' an APP.

Since the women interviewed live in a society that sees saving for retirement as a moral imperative it is not surprising that many of them, even those on very low incomes, took out non-state pensions. Their decisions were often driven by the habitus where notions of the need to rely on self rather than others are located. In addition, gendered notions about women's primary role as carer, notions located in the habitus, affected, or had previously affected, most of the women's attitudes to their paid work and their retirement. To enable women to save more effectively for their pension years, ideas about the primary role of women as carers will need to be challenged more effectively so that women (and pension providers) can see the value of preparing for the future. In addition, pension policy will have to take more effective account of the realities of women's lives and will need to steer pension policy away from traditional male patterns of employment.

The notion of reflexive decision-makers posited by Giddens (1991) suggests that individuals can be held responsible for the pension decisions they make. However, individuals are constrained by the pension options open to them, their material circumstances, their cultural capital and by having a less sceptical habitus. Thus a climate that emphasises moral responsibility, that emphasises the moral imperative to take out a non-state rather than a state scheme, where marketing strategies are used to sell pensions and where pension advice is often inadequate and confusing, the expansion of pension choice has had negative rather than positive effects. This is likely to lead to increasing poverty among women in later life.

\section{Notes}

${ }^{1}$ The present Government is discussing the possibility of reintroducing the regulation enabling employers to make occupational pension membership a condition of employment (Watt 1999).

${ }^{2}$ The topics covered biographical details, employment history, economic situation, past and present pension membership, access to pension information, knowledge about pensions and perceptions of retirement.

3.All names are pseudonyms.

${ }^{4}$ For all interviewees duration of membership refers to length of time in present scheme.

\section{references}

Agar, M., (1986), Speaking of Ethnography, Beverley Hills: Sage.

Agulnik, P., (1999), 'The Proposed State Second Pension and National Insurance' in Agulnik, A., Barr, N., Falkingham, J. and Rake, K., Partnership in Pensions? Responses to the Pensions Green Paper, CASEpaper24, Centre for Analysis of Social Exclusion, LSE: London: 1-29.

Aldridge, A., (1998), 'Habitus and cultural capital in the field of personal finance' The Sociological Review, 46, 1: 1 - 23.

Arber, S. \& Gilbert, N., (eds), (1992), Women and Working Lives: Divisions and Change, Basingstoke: Macmillan.

Bauman, Z., (1998), Work, consumerism and the new poor, Buckingham, Open University Press. 
Beck, U., (1992), Risk Society, London: Sage.

Bourdieu, P., (1984), Distinction: A Social Critique of the Judgement of Taste, London: Routledge.

Coote, A., (1998), 'Risk and Public Policy: Towards a High-Trust Democracy' in Franklin, J., (Ed), The Politics of Risk Society, Cambridge: Polity.

Davies, B. \& Ward, S., (1992), Women and Personal Pensions, London: HMSO.

Falkingham, J., (1998), 'Financial (in)security in later life' in Bernard, M. and Phillips, J., (eds), The Social Policy of Old Age: Moving into the 21st century, London: Centre for Policy on Ageing.

Field, J and Farrant, G., (1993), 'Public Perceptions of Occupational Schemes' in Goode, R. Pension Law Reform: the Report of the Pension Law Reform Committee, Vol 2, The Research, London: HMSO.

Fielding, J., (1993), 'Coding and managing data', in Gilbert, N., (Ed), Researching Social Life, London: Sage.

Gabriel, Y. and Lang, T., (1995), The Unmanageable Consumer: Contemporary Consumption and its Fragmentations, London: Sage.

Giddens, A., (1991), Modernity and Self-Identity: Self and Society in the Late Modern Age, Cambridge: Polity Press.

Giddens, A., (1998), 'Risk Society: the Context of British Politics' in Franklin, J., (Ed), The Politics of Risk Society, Cambridge: Polity.

Ginn, J. \& Arber, S., (1993), 'Pension Penalties: The Gendered Division of Occupational Welfare', Work, Employment and Society, 7, 1 :47-70.

Ginn, J. and Arber, S., (1998), "Gender and older age" in Bernard, M. and Phillips, J., (eds), The Social Policy of Old Age: Moving into the 21st century, London: Centre for Policy on Ageing.

Glaser, B and Strauss, A., (1967), The Discovery of Grounded Theory, Chicago: Aldine.

Groves, D., (1991), 'Women and financial provision for old age', in Maclean, M. and Groves, D., (eds), Women's Issues in Social Policy, London: Routledge and Kegan Paul.

Hutton, S., Kennedy, S. and Whiteford, P., (1995), Equalisation of State Pension Ages: The Gender Impact, Manchester: Equal Opportunities Commission.

Jenkins, R., (1992) Pierre Bourdieu, London: Routledge.

Leadbetter, C., (1989), 'Power to the Person' in Hall, S. and Jacques, M., (eds), New Times: The Changing Face of Politics in the 1990s, London: Lawrence and Wishart.

Macgill S., (1989), 'Risk perception and the public: insights from research around Sellafield' in Brown, J., (Ed), Environmental Threats: Perception, Analysis and Management, London: Belhaven Press.

Melucci, A., (1996), The Playing Self: Person and Meaning in the Planetary Society, Cambridge: Cambridge University Press.

Nettleton, S. and Burrows, R., (1998), 'Individualisation processes and social policy: Insecurity, reflexivity and risk in the restructuring of contemporary British health and housing policies' in Carter, J., (Ed), Postmodernity and the fragmentation of welfare, London: Routledge.

OPCS., (1990), Standard Occupational Classification, London: HMSO.

Peggs, K., (1995), Women and Pensions, PhD thesis, University of Surrey.

Pensions Management., (1992).,'Pensions Plus', Pensions Management, September.

Phillips, L., (1998), 'Hegemony and Political Discourse: The Lasting Impact of Thatcherism', Sociology, 32, 4: $847-867$. 
Reardon, A., (1994), Pension Handbook, London: Longman.

Secretary of State for Social Security., (1998), A New Contract for Welfare: Partnership in Pensions, London: HMSO, Cm 4179.

Shilling, C., (1993), The Body and Social Theory, London: Sage.

Smart, B., (1999), Facing Modernity: Ambivalence, Reflexivity and Morality, London: Sage.

Strauss, A. and Corbin, J., (1990), Basics of Qualitative Research: Grounded Theory, Procedures and Techniques, Newbury Park: Sage.

Vincent, J. A., (1995), Inequality in Old Age, London: UCL Press.

Waine, B., (1995), 'A Disaster Foretold? The Case of the Personal Pension', Social Policy and Administration, 29, 8: 317-334.

Walker, A., (1992), 'The Poor Relation: Poverty among older women', in Glendinning, C. and Millar, J., (eds), Women and Poverty in Britain: the 1990s, Brighton: Wheatsheaf.

Watt, N. (1999), 'Workers to face pension edict', The Guardian, 14 August 1999.

Wernick, A., (1991) Promotional Culture: Advertising, Ideology and Expression, London: Sage.

Williams, T. and Field, J., (1993), Pension Choices: A survey on personal pensions in comparison with other options, London: HMSO.

Your Pension., (1998), 'Transfer Values' Your Pension, Sept/Oct, Issues 5 : 39 - 40. 
Table 1: Labour Market Characteristics of the sample by second-tier pension membership

\begin{tabular}{|c|c|c|c|c|}
\hline & Seco & d-Tie & ension (n & \\
\hline & Occupational & APP & SERPS & None \\
\hline Part Time Employed & 0 & 6 & 4 & 5 \\
\hline Full Time Employed & 15 & 4 & 11 & 0 \\
\hline Occupational Class* & & & & \\
\hline 1. Managerial/Professional & 4 & 4 & 4 & 2 \\
\hline 2. Routine Non-Manual & 9 & 3 & 3 & 1 \\
\hline 3. Skilled Manual & 0 & 0 & 0 & 0 \\
\hline 4. Semi Skilled Man/Service & 2 & 2 & 7 & 0 \\
\hline Occs & 0 & 1 & 1 & 2 \\
\hline 5. Unskilled Manual & & & & \\
\hline Annual Earnings & & & & \\
\hline Up to $£ 5,000$ & 0 & 4 & 3 & 5 \\
\hline$£ 5001-£ 10,000$ & 8 & 2 & 7 & 0 \\
\hline$£ 10,001-£ 15,000$ & 6 & 3 & 5 & 0 \\
\hline$£ 15,001+$ & 1 & 1 & 0 & 0 \\
\hline Total N & 15 & 10 & 15 & 5 \\
\hline
\end{tabular}

* Using the Registrar General's Occupational Classification (OPCS 1990) collapsed into five categories. 